\title{
THERMAL COMFORT INVESTIGATION ON HOLY MOSQUE IN BANDUNG Case Study : Lautze 2 Mosque Bandung
}

\section{Agung Prabowo Sulistiawan', Syapril Wandri 2, Elvan Fauzan³, Mulvi Nizar Bahari ${ }^{4}$}

\author{
1,2,3,4 Department of Architecture, Institut Teknologi Nasional, Bandung, Indonesia \\ 1,2,3.4 JIn. P.H.H. Musthopa No. 23 Bandung 40124, Indonesia \\ Corresponding author: agung.prabowo@itenas.ac.id \\ syaprilwandri@gmail.com \\ elvanfauzan@gmail.com \\ mulvi18@gmail.com
}

Received: 18 April 2020
Revised: 26 April 2020
Article History:

Accepted: 28 April 2020
Available online: 30 April 2020

\begin{abstract}
Thermal comfort is a state of mind that expresses satisfaction with the thermal environment. There are two main categories in the effort to obtain a comfort index; empirical and analytical. Empirical is based on social surveys, while analysis is based on the physics principle of heat flow. Bandung city is one of the historical cities in Indonesia which has many historical heritage buidings. One of them which is commonly known as colonial buildings in Bandung is Lautze 2 Mosque, located at Tamblong Street in the city center of Bandung. This research was conducted to analyze the thermal comfort in the Lautze 2 Mosque Bandung. The analytical method used in this study is a quantitative research method by measuring the main factors namely air temperature, air humidity and air velocity. The main factors become obstacles to get thermal comfort data at the Lautze 2 Mosque Bandung is the location of buildings located in areas with tropical climate conditions with high air temperatures, high air humidity, and low air velocitys. The research conclude that thermal comfort in the Lautze 2 Mosque Bandung building can be categorized as uncomfortable, it can be seen from the measurement results of related factors, namely the temperature and humidity that exceeds the comfort limit and the low air velocity in the building becomes an obstacle to obtain thermal comfort.
\end{abstract}

Keywords: colonial buildings, mosque, thermal comfort, tropical climate.

\section{Introduction}

Thermal comfort is defined by the British standard BS EN ISO 7730 / ISO 77301994 and also ASHRAE 1989, which is a state of mind that expresses satisfaction with a thermal environment. Indonesia has a tropical climate which became a country which was illuminated by the sun for 12 hours, so the radiation was very high. Moreover, Indonesia is surrounded by oceans so that sunlight with high radiation causes evaporation, besides that the rainfall becomes high, this causes the air to become humid.

Bandung as one of the major city in Indonesia which has several factors that can affect thermal comfort, including the city of Bandung which is at an altitude of \pm 768 meters above sea level, with the highest point in the north with an altitude of 1,060 meters above sea level and the southern part as the lowest point of the city of Bandung with a height 675 meters above sea level.

Bandung has many historical heritages building. One of them is Lautze 2 Mosque, located in the city center of Bandung. This building is one of the colonial buildings in the shopping area, so at first glance it does not look like a mosque. This mosque is the oldest mosque built by the Chinese community and founded by a Muslim of Chinese descent, H Ali Karim in January 1997. 
This research was conducted to determine the quality of thermal comfort in the building of the Lautze 2 Mosque in Bandung, by analyzing several factors, namely air temperature, air velocity and humidity, including environmental / external and internal factors.

In order to have peaceful and spiritual experience, we must provide thermal comfort for worshippers while performing rituals and prayers. It is quite challenging to provide thermal comfort for worshippers at specified times because of prayers are perfomed at least five times at specific times (Al-Rabghi,et.al. 2017). In addition, Parkinson( 2020) stated that one of the common architectural answers for these challenges is passive design to deliver comfortable indoor environments through natural ventilations (Parkinson et.al, 2020)

\section{Theory}

a. Thermal Comfort

According to ASHRAE (American Society of Heating Refrigerating and Air Conditioning) Thermal comfort is the condition of mind that expresses satisfaction with the thermal environment, Therefore, comfort is a thought about empirical quality. Although used to interpret the body's response, thermal comfort is the satisfaction experienced by humans who accept a thermal state, this state is natural either consciously or unconsciously. The thought of a neutral temperature or a certain temperature that is suitable for someone is considered somewhat inappropriate because the comfort value is not a definite value and is always different for each individual (American Society of Heating Refrigerating and Air Conditioning, 1989; Rahadian \& Sulistiawan, 2019).

In addition, due to variation of outdoor conditions such as wind speed, solar radiation and other elements in the environment thermal comfort for humans in open spaces is much more difficult to achieve. Moreover, the thermal index of human body in indoor environment, is dependent on environmental factors such as temperature, relative humidity, air speed and mean radiant temperature, including to personal factors: human activity and clothing. (Al-Rabghi,et.al, 2017). Furthermore, the thermal comfort rely on many aspects besides air temperature, such as season, air velocity, relative humidity, clothing insulation, activity level and others. (Gou, et.al. 2018)

\section{b. Colonial Buildings}

Colonial buildings or colonial architecture is a blend of western culture and the east who came through the works of Dutch architects who were intended for the Dutch in Indonesia in the period before independence. Western influence is widely applied to various aspects of life, including urban planning and buildings. In planning and developing cities, settlements and buildings, city managers and western architects also apply local or traditional concepts that adapt to the regional climate (Wardani, 2009; Permana, 2011).

Supported by Anwar (2019) Architectural typology of colonial buildings is a response to western culture. When Dutch architects tried to innovate in building art that was different from what was commonly done in their home countries to locality with a tropical climate such as Bandung city. At that times, they efforts to find the identity of Dutch Colonial Architecture in Indonesia with reference to the traditional archipelago architecture (Java). Furthermore, C.P. Wolff Schoemaker stated that Indo-European Architecture has the following characteristics such as Building figures are generally symmetrical, have relatively similar strong vertical and horizontal rhythms and the building construction adapted to the tropical climate (Permana, 2012; Anwar et.al, 2019).

\section{c. Mosque Building.}

According to the Indonesian Dictionary (KBBI), a mosque is defined as a house or Islamic shrine building. Furthermore, according to Ministerial Decree no. 10 / KPTS / 2000, explains that a building is a building that is erected in a partly or wholly environment on or permanently in land and or water that functions as a place for humans to carry out their activities. The mosque building is included in the class 9 part $9 \mathrm{~b}$ building, which is a worship building.

\section{Methodology}

\section{a. Theoretical Method \& Inventory}

The theory was taken from journals, papers, books, standards and website. Literature review to collect all the relevant information regarding :

- thermal comfort including air temperature, air humidity and air velocity as well as environmental /external and internal factors.

- colonial architecture 


\section{b. Field Survey and Measurement}

Data collection from field survey were performed for the parameters investigated which are the air temperature, air velocity and air humidity. The measurement of the parameters investigated was carried out when the Lautze 2 Mosque Bandung is ventilated naturally.

\section{Data}

a. Location and Environmental Data Overview of Study Objects

Lautze 2 Mosque building located in the city of Bandung with a total area of $\pm 132 \mathrm{~m} 2$ and consists of 2 floors. The Lautze 2 Bandung Mosque was founded by the Haji Karim Oei Foundation (YHKO) as a center for Islamic education for Chinese people in the city of Bandung.
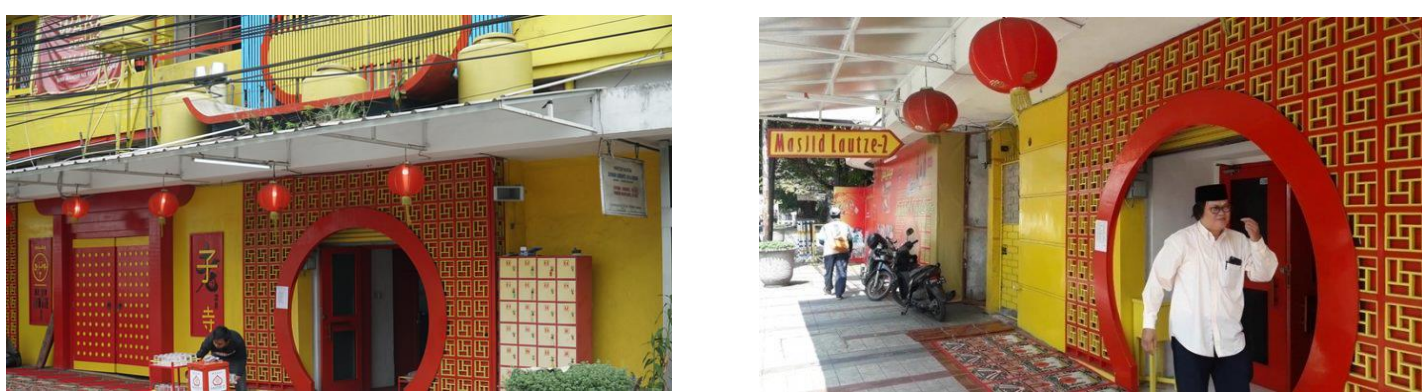

Figure 1: Surroundings of the Lautze 2 Mosque Bandung

The following is a data on average temperature and humidity based on data from the Bandung Meteorological and Geophysical Agency from 2014 to 2018, which will be one of the references in the preparation of this study.

Table 1. Average Data of Air Temperature, Air Humidity, Air Velocity in Bandung city from 20142018

\begin{tabular}{ccc}
\hline No & Variable & Average1 \\
\hline 1 & Air Temperature & $23.5^{\circ} \mathrm{C}$ \\
2 & Air Humidity & $77.3 \%$ \\
3 & Air Velocity & $4.6 \mathrm{~m} / \mathrm{s}$ \\
\hline \multicolumn{2}{c}{ Source : Badan Meteorologi Climatologi \& Geofisika Bandung }
\end{tabular}

\section{b. Building Data}

Existing conditions at the Lautze 2 Bandung Mosque building are filled with other colonial buildings, with a variety of different functions, the Lautze 2 Bandung Mosque building has a facade that is oriented towards the East, with the position of the building right in front of the city park. Around the building there are some vegetation that is not too shady, but by not giving a big effect on the influence of sunlight, because there are several large trees that stand directly opposite the building of the Lautze 2 Mosque Bandung, which becomes a buffer of sunlight during the day.

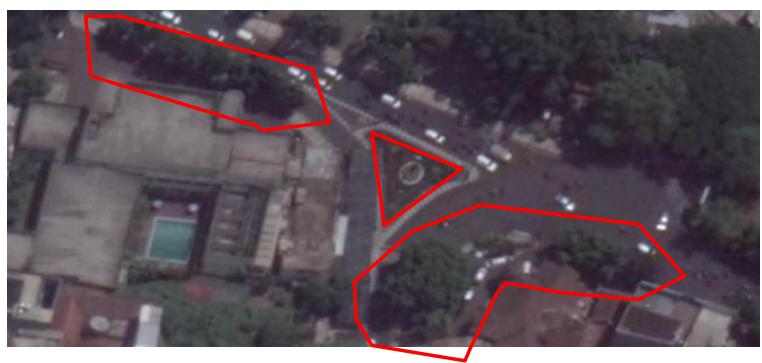

Figure 1 Existing condition of Mosque Lautze 2 Bandung from above 
The main building of the Lautze Mosque or the buildings on the right and left sides have the same characteristics, both from the type of material used, and the type of opening. The material that appears to be used after the 1st renovation is in the form of ordinary materials, such as bricks, cement plaster, ceramic floors and some wood on the ornamentation on the facades of the building. In general, the type of openings in the Lautze 2 Bandung Mosque building has characteristics of colonial buildings, but the dominant opening is on the 2nd floor of the building, while on the 1st floor there are only openings to enter area of the Mosque Lautze 2 Bandung.

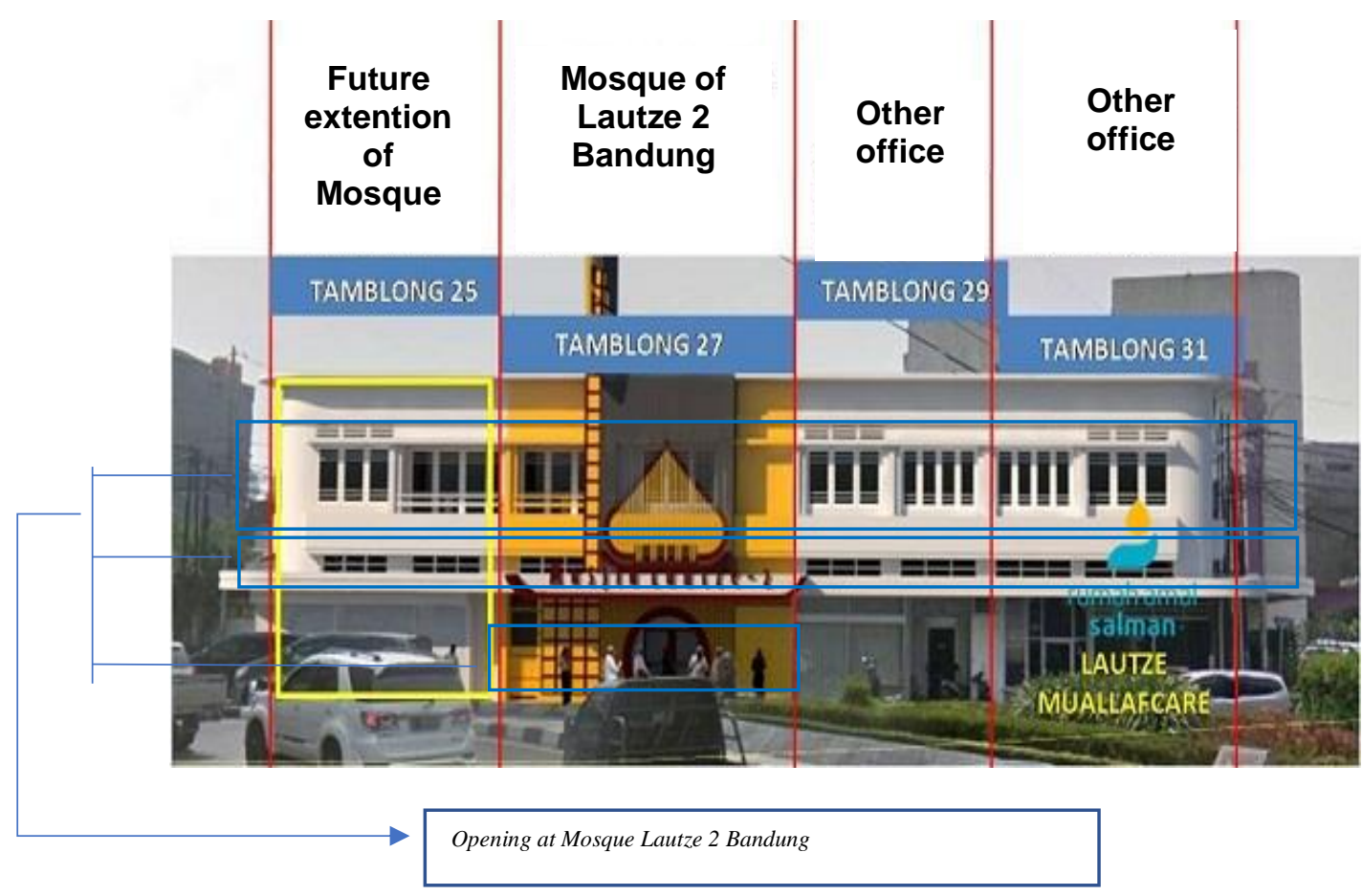

Figure 2 Façade and Division of Space Mosque Lautze 2 Bandung

\section{c. Data of Thermal Comfort Measurement}

Measurement data in this study consisted of measurement time, location of the measuring point, and measurement of external factors related to thermal comfort.

1. Measurement Time

The time of measurement was carried out on 31 October 2019, 1 November 2019, 2 November 2019, 22 January 2020, and 23 January 2020. The measurement were taken periodically at session I (04.00-06.00am), session II (10:00 to 12:00 WIB), session III (12.0015.00), and session IV (15.00-17.00), and session V (18.00-20.00 WIB). The time of this measurement is based on the time of building use for prayer time is 5 times.

2. Location of the Measurement Point

The location of the measuring point observed in this study was the space in and around the main building of the Lautze 2 Mosque in Bandung. The measurement point is only done in some spaces that are accessible to the public, because not all spaces can be accessed for public. 

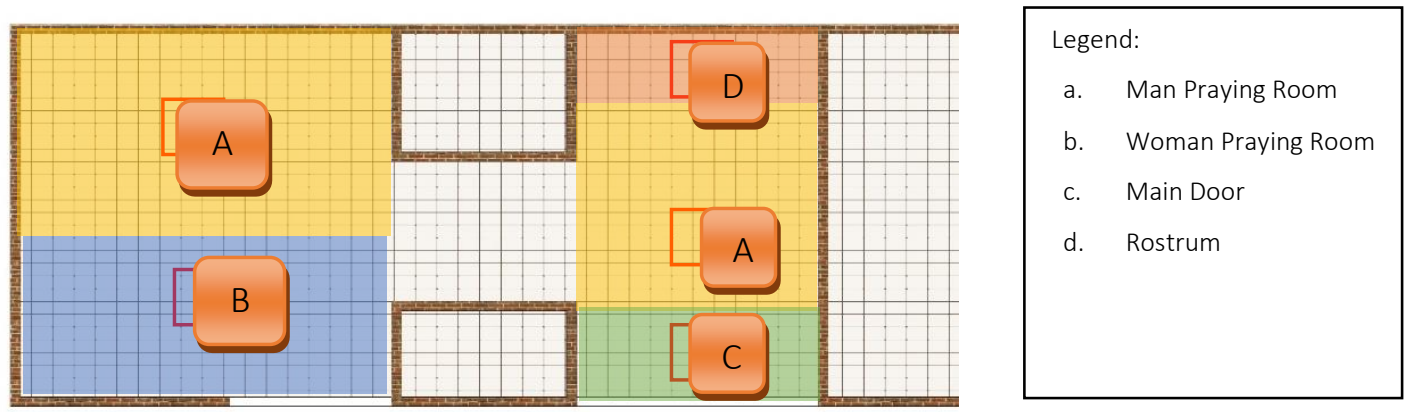

Figure 3 Space Zone of Mosque Lautze 2 Bandung

\section{Analysis}

Factors related to thermal comfort measurements are air temperature, air humidity and air velocity. The main problem on this study is the opening in the area of women's prayer that cannot be opened, so that the measurement is done in a closed door. In this study, the tool using anemometer for air temperature and air velocity, and hygrometer for measuring air humidity.

The figure 4 are tools used in the research process on thermal comfort in the Lautze 2 Mosque in Bandung namely hygrometer and anemometer.
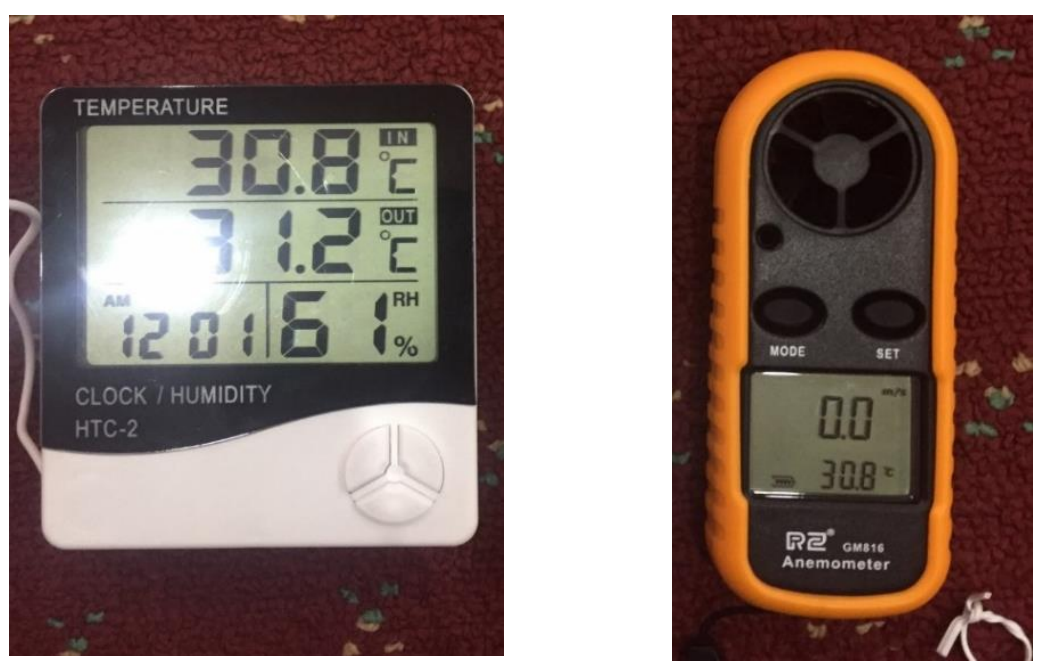

Figure 4 Hygrometer (left) and Anemometer (right)

\section{a. Air temperature}

Temperature measurements are carried out using anemometer with degree Celcius units. Measurement of air temperature is carried out at a height of $120 \mathrm{~cm}$. The following is the result of measurement of air temperature.

- Average session I $: 22.7^{\circ} \mathrm{C}$

- Average session II $: 23.7^{\circ} \mathrm{C}$

- Average session III $: 28.2^{\circ} \mathrm{C}$

- Average session IV : $22.6^{\circ} \mathrm{C}$

- Average session $\mathrm{V}: 22.5^{\circ} \mathrm{C}$ 
Table 2. Summary of Air Temperature Analysis Results

\begin{tabular}{|c|c|c|c|c|c|c|c|}
\hline Zone & & 1 & 2 & 3 & 4 & 5 & TOTAL \\
\hline \multirow[t]{2}{*}{ Session 1} & Comfort & 1 & 1 & 0 & 1 & 0 & 3 \\
\hline & uncomfort & 2 & 2 & 3 & 2 & 3 & 12 \\
\hline \multirow[t]{2}{*}{ Session 2} & Comfort & 1 & 1 & 1 & 0 & 1 & 4 \\
\hline & uncomfort & 2 & 2 & 2 & 3 & 2 & 11 \\
\hline \multirow[t]{2}{*}{ Session 3} & Comfort & 0 & 0 & 0 & 0 & 0 & 0 \\
\hline & uncomfort & 3 & 3 & 3 & 3 & 3 & 15 \\
\hline \multirow[t]{2}{*}{ Session 4} & Comfort & 1 & 0 & 1 & 0 & 1 & 3 \\
\hline & uncomfort & 2 & 3 & 2 & 3 & 2 & 12 \\
\hline \multirow[t]{2}{*}{ Session 5} & Comfort & 0 & 1 & 1 & 0 & 1 & 3 \\
\hline & uncomfort & 3 & 2 & 2 & 3 & 2 & 12 \\
\hline
\end{tabular}

Based on the table 2, almost all of the results of air temperature measurements at the Lautze 2 Mosque in Bandung are uncomfortable, especially during the daytime and late afternoon. The results from the table 2 can be concluded that the thermal comfort associated with air temperature in the Masjid Lautze 2 Bandung building is uncomfortable because the percentage of comfortable air temperatures only reaches $17.433 \%$ while the percentage of uncomfortable air temperatures reaches $82.66 \%$.

\section{b. Air Humidity}

Measurement of air humidity is carried out using a hygrometer with $\mathrm{RH} \%$ units. The following is the data from the measurement of air humidity conducted at several points in the main building space of the Lautze 2 Mosque Bandung. The following is the result of measurement of air humidity:

- Average session I : $: 70.2 \%$

- Average session II : $: 58.9 \%$

- Average session III : $63.04 \%$

- Average session IV : 69.6\%

- Average session $\mathrm{V}: 69.1 \%$

Table 3. Summary of Air Humidity Analysis Results

\begin{tabular}{|c|c|c|c|c|c|c|c|}
\hline Zone & & 1 & 2 & 3 & 4 & 5 & TOTAL \\
\hline \multirow[t]{2}{*}{ Session 1} & Comfort & 0 & 0 & 2 & 0 & 0 & 2 \\
\hline & uncomfort & 3 & 3 & 1 & 3 & 3 & 13 \\
\hline \multirow[t]{2}{*}{ Session 2} & Comfort & 0 & 0 & 0 & 3 & 3 & 6 \\
\hline & uncomfort & 3 & 3 & 3 & 0 & 0 & 9 \\
\hline \multirow[t]{2}{*}{ Session 3} & Comfort & 0 & 0 & 0 & 3 & 0 & 3 \\
\hline & uncomfort & 3 & 3 & 3 & 0 & 3 & 12 \\
\hline \multirow[t]{2}{*}{ Session 4} & Comfort & 0 & 0 & 0 & 0 & 0 & 0 \\
\hline & uncomfort & 3 & 3 & 3 & 3 & 3 & 15 \\
\hline \multirow[t]{3}{*}{ Session 5} & Comfort & 0 & 0 & 0 & 0 & 0 & 0 \\
\hline & uncomfort & 3 & 3 & 3 & 3 & 3 & 15 \\
\hline & & & & & & TOTAL & 75 \\
\hline
\end{tabular}

Based on the table 3, almost all the results of humidity measurements in the Lautze 2 Mosque Bandung building are in uncomfortable conditions. High humidity conditions can be caused by several factors including external high humidity conditions and closed opening conditions. 
In terms of humidity we can conclude that the Lautze 2 mosque Bandung is uncomfortable because the percentage of humidity is only $14.66 \%$ while the percentage of uncomfortable humidity reaches $85.33 \%$.

\section{c. Air Velocity}

According to SNI 03-6572-2001 the level to achieve comfort for air velocity is $0.25 \mathrm{~m} / \mathrm{s}$. The air velocity can be made greater than $0.25 \mathrm{~m} / \mathrm{s}$ depending on the temperature conditions of dry air in the room. Measurement of air velocity was done using anemometer with units of $\mathrm{m} / \mathrm{s}$. This measurement is carried out at elevation of $120 \mathrm{~cm}$.

The following are data on the results of air velocity measurements conducted at several points in the main building space of the Lautze 2 Mosque Bandung.

- Average session I : $0.24 \mathrm{~m} / \mathrm{s}$

- Average session II : $0.08 \mathrm{~m} / \mathrm{s}$

- Average session III $: 0.1 \mathrm{~m} / \mathrm{s}$

- Average session IV : $0.09 \mathrm{~m} / \mathrm{s}$

- Average session $\mathrm{V}: 0.16 \mathrm{~m} / \mathrm{s}$

Table 4. Summary of Air Velocity Analysis Results

\begin{tabular}{|c|c|c|c|c|c|c|c|}
\hline Zone & & 1 & 2 & 3 & 4 & 5 & TOTAL \\
\hline \multirow[t]{2}{*}{ Session 1} & Comfort & 2 & 0 & 0 & 3 & 1 & 6 \\
\hline & uncomfort & 1 & 3 & 3 & 0 & 2 & 9 \\
\hline \multirow[t]{2}{*}{ Session 2} & Comfort & 0 & 0 & 0 & 0 & 0 & 0 \\
\hline & uncomfort & 3 & 3 & 3 & 3 & 3 & 15 \\
\hline \multirow[t]{2}{*}{ Session 3} & Comfort & 0 & 0 & 0 & 0 & 0 & 0 \\
\hline & uncomfort & 3 & 3 & 3 & 3 & 3 & 15 \\
\hline \multirow[t]{2}{*}{ Session 4} & Comfort & 0 & 0 & 0 & 0 & 0 & 0 \\
\hline & uncomfort & 3 & 3 & 3 & 3 & 3 & 15 \\
\hline \multirow[t]{3}{*}{ Session 5} & Comfort & 0 & 0 & 0 & 2 & 0 & 2 \\
\hline & uncomfort & 3 & 3 & 3 & 1 & 3 & 13 \\
\hline & & & & & & TOTAL & 75 \\
\hline
\end{tabular}

According to SNI 03-6572-2001, standard for Good air velocity is $0.25 \mathrm{~m} / \mathrm{s}$. The air velocity can be made greater than $0.25 \mathrm{~m} / \mathrm{s}$ depending on the temperature conditions of dry air in the room. Based on the table 4, the thermal comfort in terms of air velocity in the Lautze 2 Mosque Bandung is uncomfortable because the percentage of comfortable air velocity is $10.66 \%$ while the percentage of uncomfortable air velocity reaches $89.33 \%$.

\section{Conclusion}

Based on the results of research conducted on the building of the Lautze 2 Mosque in Bandung, it can be concluded that thermal comfort in Lautze 2 Bandung Mosque are:

1. The Lautze 2 Bandung Mosque building can be categorized not suitable for standard of thermal comfort, it can be seen from the measurement results of related factors, namely the temperature and humidity that exceeds the comfort limit and the low air velocity in the building becomes an obstacle to obtain thermal comfort at the Lautze 2 Bandung Mosque building. The design of building openings cannot yet support thermal comfort due to openings that are not on each side of the building, due to the building being flanked by other buildings, also one of the openings which is not functioned optimally for natural ventilation in the building.

2. Based on the results of measurements of air temperature using an anemometer, at 5 different sessions in each room, almost all buildings of the Lautze 2 Bandung Mosque are in uncomfortable conditions. The results of the measurement of air humidity using a hygrometer in each room at five different sessions, showed the Lautze 2 Mosque Bandung building in uncomfortable conditions with the percentage of comfortable air humidity that only reached $14.66 \%$, while the percentage of uncomfortable air humidity reached $85.33 \%$. . The results of the measurement of 
air humidity using a hygrometer in each room at five different sessions, showed the building of Masjid Lautze 2 Mosque Bandung in uncomfortable conditions with the percentage of comfortable air temperatures reaching only $17.33 \%$, while the percentage of uncomfortable air temperatures reaching $82.66 \%$. As for the air velocity measured using anemometer in each room at five different sessions, it shows the building of the Lautze 2 Mosque Mosque in uncomfortable conditions with the percentage of comfortable air velocity reaching only $10.66 \%$, while the percentage of uncomfortable air velocity reaching $89.33 \%$.

3. Based on the design of the location of the building opening of Lautze 2 Mosque Bandung has a few openings, which is only at the entrance of the building. This limited number of openings causes air velocity is not optimal, this makes it difficult to obtain thermal comfort in the building. Therefore it can be concluded that the design of openings related to openings in the building of Lautze 2 Mosque Bandung is lacking to support thermal comfort.

\section{References}

Al-Rabghi, Omar M., Abdulaziz S. Al-Ghamdi, Mazen M. Kalantan. (2017). Thermal Comfort Around the Holy Mosques. Arab J Sci Eng (2017) 42:2125-213

Anwar, Hendi, Nur Arief Hapsoro (2019). Facade Identification of colonial buildings in the city of Bandung. 6th Bandung Creative Movement International Conference in Creative Industries (6th BCM 2019).

Ashrae, Standard Thermal Environmental Conditions for Human Occupancy, American Society of Heating Refrigeration and Air Conditioning Engineer ( ASHRAE), Atlanta, USA

Bandung Meteorology Climatology \& Geophysics Agency https://www.jabarprov.go.id/En/index.php/news/3155/Meteorological Climatological and Geophysical Agency BMKG

British Standard BS EN ISO 7730/ISO 7730 (1994) for Thermal Comfort.

Fanger, P.O. (1970).Thermal Comfort, Analysis and Application in Environmental Engineering.McGraw-Hill Book Company.

Gou, Zhonghua, Wajishani Gamage, Stephen Siu-Yu Lau and Sunnie Sing-Yeung Lau,(2018). An Investigation of Thermal Comfort and Adaptive Behaviors in Naturally Ventilated

Parkinson, Thomas, Richard de Dear, Gai Brager. (2020). Nudging The Adaptive Thermal Comfor Model. Energy \& Buildings 260.

Permana, A. Y. (2011). Penerapan Konsep Perancangan Smart Village sebagai Local Genius Arsitektur Nusantara. Jurnal Arsitektur Komposisi, 9(1), 24-33.

Permana, A. Y. (2012). Eco-architecture Sebagai Konsep Urban Development di Kawasan Slums dan Squatters Kota Bandung. (September), 1-11. Semarang.

Rahadian, E. Y., \& Sulistiawan, A. P. (2019). The Evaluation of Thermal Comfort using a BIM-based Thermal Bridge Simulation. 1(2), 129-138. https://doi.org/10.17509/jare.v1i2.22304

Szokolay, S.V. (1980). Environmental Science Handbook for Architecs and Engineer. NewYork Lippsmeier, George.(1994). Bangunan Tropis. Erlangga

Wardani, Laksmi Kusuma. (2009).Gaya Desain Kolonial Belanda pada Interior Gereja Katolik Hati Kudus Yesus Surabaya. Universitas Kristen Petra. Surabaya 